М.М. Корощенко ${ }^{1}$, О.Л. Харитонов ${ }^{1}$, А.М. Гордієнко ${ }^{2}$

${ }^{1}$ Інститут Військово-Морських Сил “Одеської національної морської академії”, Одеса

${ }^{2}$ Харківський національний університет Повітряних Сил ім. І. Кожедуба, Харків

\title{
ПРОТИПОВІТРЯНА ОБОРОНА КОРАБЛІВ (КАТЕРІВ) ВІЙСЬКОВО-МОРСЬКИХ СИЛ УКРАЇНИ У "ВІЙНІ ДРОНІВ": ПРОБЛЕМИ ТА ШЛЯХИ ПІДВИЩЕННЯ ЕФЕКТИВНОСТІ
}

В статті розглянуто питання щзодо протиповітряної оборони кораблів (катерів) Військово-Морських Сил Украӥни від малорозмірних безпілотних засобів повітряного нападу (дронів). Проведений аналіз бойового застосування та порядок дій у сучасних військових конфліктах малорозмірних безпілотних літальних апаратів (БпЛА). Проведений узагальнений аналіз можливостей засобів протидії БпЛА провідних краӥн світу та України. Надані пропозиції щзодо покращзення протиповітряної оборони (можливості протидії) кораблів (катерів) ВМС Украӥни від малорозмірних БпЛА - дронів.

Ключові слова: протиповітряна оборона, дрони, кораблі, катери, способи бойового застосування, бойові можливості, тактика бойового застосування, принципи (основи) побудови зенітного ракетного комплексу.

\section{Вступ}

Постановка проблеми. Аналіз локальних війн та військових конфліктів сучасності показує, що для виконання поставлених завдань угрупованнями збройних сил протидіючих сторін активно застосовуються малорозмірні безпілотні літальні апарати (дрони).

Дрон (англ. drone - трутень) - безпілотний літальний апарат (БпЛА) військового чи цивільного призначення, різновид військового робота; в ширшому сенсі - мобільний, автономний апарат, запрограмований на виконання визначених бойових завдань.

Військові дрони найбільш часто застосовуються для виконання завдань, пов'язаних з розвідкою противника та нанесення по ньому ударів.

Тому, в сучасних війнах та військових конфліктах широке застосування знайшли розвідувальні та ударні дрони.

Наприклад, у війні в Сирії масово були застосовані турецькі ударні дрони 3 великою тривалістю польоту “Bayraktar TB2” (“Прапороносець”). Цей дрон має зльотну масу 650 кг, вантажопідйомність 55 кг, крейсерську швидкість 130 км/год, радіус діїдо 150 км, максимальну стелю - 8200 метрів та автономність польоту - 24 години. "Bayraktar ТВ2" може нести керовані ракети та авіаційні бомби.

Аналіз бойових дій у Сирії [1] показує, що БпЛА "Bayraktar ТВ2" та інші ударні дрони проривали протиповітряну оборону і знищували не тільки важливі наземні цілі та озброєння сирійської армії, а й самі засоби протиповітряної оборони: зенітний ракетно-гарматний комплекс (ЗРГК) “Панцирь-С1", ЗРК 9К330 “Тор”, ЗРК С-125 “Печора-2А”.

Також, можливе застосування БпЛА, у тому числі й малорозмірних, по кораблях (катерах) ВМС України. Тому, тематика робіт, що пов'язана з організацією прикриття підрозділів ВМС від БПЛА $є$ актуальною.

Аналіз останніх досліджень і публікацій. Аналіз застосованя турецьких ударних дронів у війні в Сирії “Bayraktar ТВ2” [1-2], продемонструвала зрілість концепції бойового застосування ударних БАК. Безпілотники виявилися дуже ефективним елементом сучасної війни та яскраво свідчить, яку важливу роль відіграють сучасні технології, як бойові дрони реально можуть змінити хід бойових дій.

За офіційними підрахунками Міністерства оборони Туреччини, армія Асада втратила понад 200 одиниць бронетехніки, близько 50 одиниць артилерійського озброєння та РСЗВ, близько 100 одиниць автотехніки та понад 3 тисячі військових. При цьому переважна більшість втрат була нанесена саме ударами “Bayraktar TB2” або за їх наведення на ціль інших високоточних ракет [3].

В роботах [4-6] наведено порядок застосування БАК з використанням високоточних керованих боєприпасів, так і виконання завдань, таких, як розвідка, спостереження, наведення й коригування вогню артилерії, що свідчить про утримання провідних позицій за показниками бойового застосування у світі.

Аналіз робіт [6-8], які присвячені питанням протиповітряної оборони кораблів (катерів) ВМС 
України у “війні дронів” показав, що даному питанню приділено недостатньо уваги.

Мета статті. Метою статті є розробка пропозицій щодо організації протиповітряної оборони кораблів (катерів) ВМС України від малорозмірних безпілотних засобів повітряного нападу.

\section{Виклад основного матеріалу}

Відомо, що є ЗРК, які спроможні вести ефективну боротьбу з усіма існуючими та перспективними засобами повітряного нападу. В першу чергу до них можна віднести потужні ЗРК С-400, С-300ПМУ, "Patriot", С-300ПС. Усі ці комплекси мають високі потенційні вогневі можливості.

Наприклад, на думку військових фахівців Російської Федерації, найпотужнішим комплексом у боротьбі з сучасними та перспективними засобами повітряного нападу у світі являється ЗРК С-400, який має потенційну максимальну межу зони ураження до 240 км.

Однак, аналіз бойового застосування сучасних російських зенітних ракетних комплексів показує, що реалізувати свої вогневі можливості ЗРК С-400, С-300ПС, С-300ПМУ у боротьбі з сучасними малорозмірними БпЛА (дронами) сьогодні практично неможливо. Це викликано тим, що всі їх технічні характеристики (наприклад, радіолокаційного приймача та передавального пристрою) між собою збалансовані, вони визначають максимальні можливості комплексів по боротьбі з будь-якими пілотованими повітряними засобами, крилатими та тактичними балістичними ракетами. При цьому, покращення одних технічних характеристик, які дозволять, наприклад, збільшити дальність виявлення малорозмірних повітряних засобів, спричинить погіршення інших тактичних можливостей ЗРК. Так, для збільшення дальності виявлення малорозмірних повітряних засобів (дронів) необхідно збільшувати чутливість приймального пристрою комплексу або збільшувати потужність передавального пристрою. Зміна цих технічних характеристик призведе до погіршення перешкодозахищеності комплексу.

Сучасні ЗРК, за своїми тактико-технічними характеристиками, не спроможні своєчасно виявляти малорозмірні БПЛА та забезпечити їх знищення на дальній межі зони ураження. В кращому випадку обстріл цих цілей може бути здійснений в глибині зони ураження, в гіршому - на ближній межі зони ураження або взагалі можливості їх обстрілу не буде. Так, при застосуванні групових ударів дронів типу "Bayraktar ТВ2", як це було в Сирії, система зенітного ракетного вогню на основі ЗРК С-400 та зенітного гарматно-ракетного комплексу "ПанцирьC1” була не в змозі ефективно їм протидіяти.

Але, ж ці дрони мають не найкращі тактикотехнічні характеристики серед сучасних ударних дронів. Їх розмір та ефективна відбиваюча поверхня більші, ніж деякі аналогічні ударні дрони провідних держав світу.

Боротися з дронами, які мають ще меншу ефективну поверхню розсіяння стає практично неможливим навіть найсучаснішим комплексам типу C300ПС, С-300ПМУ, С-400 та іншим ЗРК, які мають аналогічні “класичні” принципи (основи) побудови та існуючі принципи бойового застосування, які були розроблені ще Ф.К. Неупокоевим у 80 -х роках минулого століття.

Аналіз бойового застосування в Сирії дронів типу “Bayraktar ТВ2" і сучасних зенітних ракетних (гарматно-ракетних) комплексів російського виробництва наглядно показав те, що сучасні та перспективні ЗРС (ЗРК), які розроблені та розробляються сьогодні у світі по існуючих класичних принципах (основах) побудови ЗРК, неспроможні ефективно боротися з малорозмірними безпілотними літальними апаратами (дронами).

Для розробки комплексів, які б були спроможні ефективно боротися $з$ малорозмірними БпЛА необхідно вирішити проблемні питання, які мають існуючі ЗРК. Основними з них є:

- мала дальність виявлення малорозмірних БпЛА;

- час реакції (робітний час) існуючих ЗРК не дозволяє своєчасно обстріляти малорозмірні БПЛА;

- тривалий час переводу ЗРК в готовність до бою;

- значно мала імовірність ураження малорозмірних БПЛА в порівнянні з літаками і крилатими ракетами;

- вартість витрат на знищення дронів ЗРК значно перевищує вартість самого дрона.

Одним 3 шляхів вирішення першої проблеми може бути наближення засобів розвідки до імовірної траєкторії польоту дронів, тобто їх винесення на напрямок удару дронів.

Для вирішення другої проблеми може бути застосований автоматичний захват цілі на супроводження (що навіть теоретично неможливо реалізувати), або застосування інших принципів виявлення та супроводження дронів, наприклад, оптикоелектронне або (та) інфрачервоне виявлення та супроводження.

Третя проблема може бути вирішена шляхом забезпечення постійної готовності засобів ППО до знищення повітряної цілі.

Четверта проблема може бути вирішена шляхом збільшення впливів по цілі.

Для вирішення п'ятої проблеми необхідно застосовувати засоби ураження повітряної цілі, вартість яких буде приблизно однаковою 3 вартістю цих дронів.

Тобто, загальними шляхами підвищення 
ефективності засобів ППО у боротьбі з дронами можуть бути наступні:

- удосконалення (модернізація) існуючих ЗРК, що прирівнює до створення нового ЗРК;

- зміна поглядів на принципи (основі) побудови ЗРК, принципи їх бойового застосування та, на цій основі, створення нових комплексів боротьби 3 дронами;

- удосконалення основних (розробка нових) способів бойового застосування засобів ППО при боротьбі з дронами.

Таким чином, для боротьби з малорозмірними БПЛА необхідно створення:

- принципово нових вогневих комплексів (систем) протиповітряної оборони;

- засобів радіоелектронної боротьби з дронами.

Необхідно відзначити, що більшість військових фахівців у світі віддають перевагу у боротьбі з дронами (або рахують це єдиним шляхом) застосування засобів РЕБ проти них. Сьогодні, у багатьох державах світу створені та $\epsilon$ на озброєнні спеціальні засоби РЕБ, які ефективно протидіють дронам шляхом подавлення системи управління ними. Також, активно продовжуються роботи щодо подальшого удосконалення цих засобів та розробки нових, більш ефективних у боротьбі з малорозмірними БпЛА.

В Україні також розроблені сучасні вітчизняні комплекси РЕБ, які спроможні вести боротьбу 3 дронами. До них відносяться наступні комплекси: “Анклав-УТ”, “Мандат-Б1Е”, “Буковель-АД”, “Нота", “Хмара-2”, “Полонез”. Розглянемо коротко їх призначення та основні тактичні характеристики.

Комплекс “Анклав-УТ” призначений для створення перешкод для приймачів, що працюють на частотах навігаційних систем GLONASS та GPS, а також для подавлення каналів управління та телеметрії, які використовуються на сучасних БПЛА та високоточному озброєнні. Дальність дії комплексу не менш 15 км.

Комплекс РЕБ Р-330УМ “Мандат-Б1Е” призначений для виявлення, пеленгування та аналізу сигналів сучасних засобів радіозв'язку, з метою визначення координат джерел радіовипромінювання i створення радіоперешкод каналам зв'язку. Він забезпечує постановку прицільних за частотою і часом, а також загороджувальних радіоперешкод наземним засобам зв'язку.

Комплекс “Буковель-АД” призначений для виявлення БпЛА противника та блокування сигналів передачі даних, управління та навігації за допомогою систем позиціювання GPS/GLONASS у радіусі до 15 км.

Комплекс “Нота” призначений для подавлення систем супутникового зв'язку всіх стандартів та протидії засобам РЕБ і контрбатарейним радарам. Він має два типи антен - направлені та кругові (все- направлені). Кругові антени забезпечують загальне прикриття стаціонарних об'єктів, направлені працюють по конкретному вузькому секторі. Дальність дії комплексу не менш 20 км.

Комплекс "Хмара-2" призначений для виявлення БпЛА із застосуванням засобів пасивної локації (радіопеленгації) в діапазоні частот 230...3000 МГц. Він забезпечує постановку перешкод каналам управління БпЛА в основних діапазонах частот, сигналам Wi-Fi i сигналам систем супутникової навігації. Він дозволяє здійснювати подавлення систем радіозв'язку. Дальність подавлення приймачів сигналів навігаційних систем складає до 30 км, а каналів управління і передачі даних БпЛА - до 15 км.

Комплекс РЕБ “Полонез” призначений для виявлення малорозмірних БпЛА, видачі по них інформації та подавлення команд управління і телеметрії навігаційних каналів систем GPS/GLONASS в зоні до 40 км - при застосуванні направленої антени і до 20 км при застосуванні ненаправленої антени. У якості засобів розвідки у комплексі застосовується радіолокаційна станція міліметрового діапазону “Лис-3М”, а також оптико-електронний модуль для захоплення і супроводження повітряних цілей в тепловізійному та інфрачервоному випромінюванні. Комплекс “Полонез” може також передавати інформацію про виявлені БпЛА на командний пункт для подальшого їх знищення.

В багатьох державах світу також розроблені системи для боротьби з дронами. Наприклад, у Великобританії розроблена система “Anti-UAV Defence System” (AUDS). Ця система забезпечує дальність ураження дронів до 2,5 км включно та має час реакції $15 \mathrm{c}$.

Російська автоматизована станція перешкод Р-330Ж “Борисоглебськ-2” забезпечує:

- автоматизоване виявлення, пеленгування, та аналіз сигналів джерел радіовипромінювання в робочому діапазоні частот;

- постановку радіоперешкод мобільним наземним станціям (абонентським терміналам) систем супутникового зв'язку "ІНМАРСАТ" та "Іридіум", навігаційній апаратурі споживачів супутникової навігаційної системи "NAVSTAR" (GPS) і базовим станціям стільникового зв'язку GSM-900/1800;

- автоматизоване ведення телекодового інформаційного обміну з аналогічною станцією для забезпечення синхронного пеленгування джерел радіовипромінювання з метою розрахунку їх координат;

- автоматизоване ведення телекодового інформаційного обміну з пунктом управління;

- автоматичне тестування апаратури і виявлення несправних елементів (складових частин).

Аналіз характеристик існуючих комплексів та систем боротьби 3 дронами показав, що усі вони мають однакові недоліки: 
- відносна мала дальність виявлення дронів відносно об'єктів прикриття і, відповідно, мала зона подавлення системи управління ними;

- низька живучість цих комплексів.

Мала дальність виявлення дронів відносно об'єктів прикриття, обумовлена технічними характеристиками засобів виявлення та розміщенням їх близько до цих об'єктів. Збільшення дальності виявлення дронів можна досягти шляхом виносу засобів виявлення у бік імовірного противника.

Підвищення живучості комплексів можна досягти застосуванням засобів фізичного знищення дронів та розміщенням їх у повітрі на напрямку їх атаки.

Тобто, сьогодні оптимальним комплексом боротьби з дронами може стати мобільний повітряний комплекс, до складу якого раціонально включити засоби виявлення та цілевказівки, наведення, ураження, які пропонується розташувати на платформі своїх дронів, назвемо їх антидронами.

Таким чином, весь комплекс боротьби з дронами можна назвати повітряним комплексом боротьби 3 малорозмірними БпЛА - дронами (ПКБД).

Пропонується створення цього комплексу в різних варіантах, які відрізняються один від одного місцем знаходження засобів виявлення та цілевказівки, наведення, ураження. Наприклад, ці засоби можуть знаходитися як на одному антидроні, так на базі різних дронів. При цьому, засобами ураження можуть бути малокаліберні гармати, гладкоствольні автомати, гвинтівки або лазерні та інші установки. Також, необхідно відзначити, що засобом ураження може бути і сам антидрон, коли він здійснює таран цілі. В цьому випадку назвемо його дрономвинищувачем.

Принцип бойового застосування ПКБД полягає у чергуванні в повітрі цього комплексу при загрозі атаки дронів противника на напрямку їх удару, своєчасному виявленню повітряного противника, видачі цілевказівки на засоби ураження при розносі їх с засобами виявлення та цілевказівки або повітряної атаки дрона-винищувача по противнику.

\section{Висновки}

Існуючі зенітні ракетні системи і комплекси, які мають високі потенціальні тактико-технічні характеристики, неспроможні ефективно боротися 3 малорозмірними БпЛА типу дронів.

Удосконалення цих систем і комплексів або створення нових згідно існуючих принципів (основ) побудови ЗРК не допоможе набагато підвищити можливості зі знищення малорозмірних БпЛА.

Тому, запропоновано створення перспективних повітряних комплексів боротьби з малорозмірними БпЛА - дронами. Ці комплекси будуть спроможні надійно прикривати з повітря не тільки кораблі (катери) ВМС, а й інші важливі державні та військові об’єкти. При відбитті масованого (зосередженого) удару повітряного противника вони можуть застосовуватися сумісно з існуючими ЗРК.

\section{Список літератури}

1. Заболотний В.І. Дроноцентричний удар [Електронний ресурс] / В.І. Заболотний // Тиждень. - Режим доступу: https://tyzhden.ua/World/241711.

2. Турецькі дрони змінили тактику війни. Які висновки для України [Електронний ресурс] // Військовий навігатор України. - Режим доступу: http://surl.li/eupz.

3. [Електронний ресурс] Оперативно-тактичні багатоцільові безпілотники Bayraktar ТВ2 виробництва турецької компанії Baykar Makina налітали вже 200 тисяч годин / Defense Express. - Режим доступу: https:/defenceua.com/news/udarni_bpla_bayraktar_tb2_nalitali_rekordni_200_tisjach_godin_video-950.html.

4. [Електронний ресурс] Як ударні турецькі дрони змінили тактику війни / Defense Express // Режим доступу: http://surl.li/euov.

5. [Електронний ресурс] Турецкая армия усилила возможности воздушной поддержки с помощью 8 новых вооруженных дронов / Daily Sabah. - Режим доступу: https://www.dailysabah.com/defense/2018/03/22/turkish-army-reinforces-airsupport-capability-with-8-new-armed-drones.

6. Фещенко А.Л. Застосування БПЛА у військових конфліктах кінця XX - початку XXI ст. / А.Л. Фещенко // Військова історія. - К.: НУОУ, 2011. - 20 с.

7. Аминов С. ПВО в борьбе с БПЛА / С. Аминов // Беспилотная авиация: спецвыпуск МАКС. - 2011. - С. 34-36.

8. Шулежко В.В. Основні напрямки розвитку та застосування безпілотних літальних апаратів / В.В. Шулежко. К.: МО України, 2013. -65 с.

9. Неупокоев Ф.К. Противовоздушный бой / Ф.К. Неупокоев. - М.: Военное издательство, 1989. - 261 с.

10. Теорія і техніка протидії безпілотним засобам повітряного нападу. Кн. 1. Безпілотні засоби повітряного нападу. Застосування та перспективи розвитку. Виявлення малопомітних засобів повітряного нападу: монографія / B.I. Ткаченко, Ю.Г. Даник, Г.А. Дробаха, В.І. Карпенко, Р.Е. Пащенко, С.Б. Смирнов. - Х.: ХВУ, 2002. - 212 с.

11. Моделювання бойових дій військ (сил) протиповітряної оборони та інформаційне забезпечення процесів управління ними (теорія, практика, історія розвитку): монографія / В.П. Городнов, Г.А. Дробаха, М.О. Ермошин, С.Б. Смирнов, В.І. Ткаченко. - Х.: ХВУ, 2004. -410 с.

12. Родіонов І.М. Військова енциклопедія / І.М. Родіонов. - М.: Військове видавництво, 1994. - Т. 1. - 328 с. 
13. Єрмошин М.О. Боротьба в повітрі / М.О. Єрмошин, В.М. Федай. - Х.: ХВУ, 2004. - 381 с.

14. [Електронний ресурс] Тактика військово-морських сил. - Одеса: Інститут ВМС. -2017.

15. [Електронний ресурс] Довідник НАТО. - Режим доступу: https://www.nato.int/docu/other/ukr/ handbook/2001/pdf/handbook.pdf.

16. Офіційний сайт MIL.IN.UA. ХК “Укрспецтехніка". - Режим доступу: https://mil.in.ua/forum/ viewtopic.php? $\mathrm{f}=44 \& \mathrm{t}=6197$.

17. Гордиенко Ю.В. Военная авиация / Ю.В. Гордиенко, В.П. Морозов, А.С. Прибылов. - Монино: ООО "Попури", 1999. -82 c.

18. Касаткин А. Структура коалиционных органов управления ОВС НАТО / А. Касаткин // Зарубежное военное обозрение. - 2002. - № 5. - С. 2-5.

19. Довідник з протиповітряної оборони / А.Я. Торопчин, І.О. Романенко, Ю.Г. Даник, Р.Е. Пащенко та ін. - К.: МО України, 2003. - 260 с.

20. Дрожжин А.И. Воздушные войны в Ираке и Югославии / А.И. Дрожжин, Е.В. Алтухов. - М.: ООО “Восточный горизонт”, 2002. - $121 \mathrm{c}$.

21. Zherebilova A.A. Modern military aviation / A.A. Zherebilova. - Smolensk: Rusich, 2000. - 832 c.

\section{References}

1. Zabolotny, V.I. (2020), "Dronocentrichnij udar" [Drone-centric strike], Week, available at: www.tyzhden.ua/World/241711 (accessed 27 March 2020).

2. (2020), "Turec'ki droni zminili taktiku vijni. Yaki visnovki dlya Ukraïni” [Turkish drones changed the tactics of war. What are the conclusions for Ukraine], Military navigator of Ukraine, available at: http://surl.li/eupz.

3. (2020), "Operativno-taktichni bagatocil'ovi bezpilotniki Bayraktar TB2 virobnictva turec'koï kompaniï Baykar Makina nalitali vzhe 200 tisyach godin" [Operativno-taktichni bagatocil'ovi bezpilotniki Bayraktar TB2 virobnictva turec'koï kompaniï Baykar Makina nalitali vzhe 200 tisyach godin], Defense Express, available at: www.defenceua.com/news/udarni_bpla_bayraktar_tb2_nalitali_rekordni_200_tisjach_godin_video-950.html.

4. (2020), "Yak udarni turec'ki droni zminili taktiku vijni" [How Turkish drones changed the tactics of war], Defense Express, available at: http://surl.li/euov.

5. (2018), "Tureckaya armiya usilila vozmozhnosti vozdushnoj podderzhki s pomoshch'yu 8 novyh vooruzhennyh dronov" [Turkish army strengthens air support capabilities with 8 new armed drones], Daily Sabah, available at: www.dailysabah.com/defense/2018/03/22/turkish-army-reinforces-air-support-capability-with-8-new-armed-drones.

6. Feshchenko, A.L. (2011), "Zastosuvannya BPLA u vijs'kovih konfliktah kincya XX-pochatku XXI st." [Stagnation of UAVS in the conflicts of the 20th century - the ear of the 21st century], Military history, NUOU, Kyiv.

7. Aminov, S. (2011), "PVO v bor'be s BPLA" [Air defense in the fight against UAVs], Unmanned aircraft: special issue MAKS, pp. 34-36.

8. Shulezhko, V.V. (2013), "Osnovni napryamki rozvitku ta zastosuvannya bezpilotnih lital'nih aparativ" [The main directions of development and application of unmanned aerial vehicles], MO of Ukraine, Kyiv, 65 p.

9. Neupokoev, F.K. (1989), "Protivovozdushnyj boj” [Aircraft battle], Military publishing house, Moscow, 261 p.

10. Tkachenko, V.I., Danyk, Y.G., Drobaha, G.A., Karpenko, V.I., Pashchenko, R.E. and Smirnov, E.B. (2002), "Teoriya $i$ tekhnika protidii bezpilotnim zasobam povitryanogo napadu. Kn. 1. Bezpilotni zasobi povitryanogo napadu. Zastosuvannya ta perspektivi rozvitku. Viyavlennya malopomitnih zasobiv povitryanogo napadu" [Theory and technique of counteracting unmanned aerial vehicles. Book 1. Unmanned aerial vehicles. Application and prospects of development. Detection of inconspicuous means of air attack], KhVU, Kharkiv, $212 \mathrm{p}$.

11. Gorodnov, V.P., Drobaha, G.A., Yermosin, M.O., Smirnov, S.B. and Tkachenko V.I. (2004), “Modelyuvannya bojovih dij vijs'k (sil) protipovitryanoï oboroni ta informacijne zabezpechennya procesiv upravlinnya nimi (teoriya, praktika, istoriya rozvitku)" [Modeling of combat operations of troops (forces) of air defense and information support of their management processes (theory, practice, history of development)], KhVU, Kharkiv, $410 \mathrm{p}$.

12. Rodionov, I.M. (1994), "Vijs'kova enciklopediya" [Military encyclopedia], Military Publishing House, Moscow, Vol. 1, 328 p.

13. Yarmoshin, M.O. and Feday, V.M. (2004), "Borot'ba v povitri" [Fighting in the air], KhVU, Kharkiv, 381 p.

14. (2017), "Taktika vijs'kovo-mors'kih sil" [Manual The tactics of the military-naval forces], Institute of the Navy, Odessa.

15. (2001), "Dovidnik NATO" [NATO Handbook], available at: www.nato.int/docu/other/ukr/ handbook/2001/pdf/handbook.pdf.

16. The official site of MIL.IN.UA. (2020), "HK “Ukrspectekhnika"”' [The website of HC Ukrspetstekhnika], available at: www.mil.in.ua/forum/viewtopic.php? $\mathrm{f}=44 \& \mathrm{t}=6197$.

17. Gordienko, Yu.V., Morozov, V.P. and Pribylov, A.S. (1999), "Voennaya aviaciya" [Military aviation Arrived], OOO "Popuri”, Monino, $82 \mathrm{p}$.

18. Kasatkin, A. (2002), "Struktura koalicionnyh organov upravleniya OVS NATO" [The structure of the coalition governing bodies of NATO], Foreign military review, No. 5, pp. 2-5.

19. Toropchin, A.Ya., Romanenko, I.O., Danik, Yu.G. and Pashchenko, R.E. (2003), “Dovidnik z protipovitryanoï oboroni" [Handbook of air defense], Ministry of Defense of Ukraine, Kyiv, 260 p.

20. Drozhzhin, A.I. and Altukhov, E.V. (2002), "Vozdushnye vojny v Irake i Yugoslavii” [Air wars in Iraq and Yugoslavia], LLC "Eastern Horizon", Moscow, 121 p. 
21. Andreev, S.G., Babkin, A.V. and Baum, F.A. (2002), "Fizika vzryiva" [Physics of the explosion], Fizmatlit, Moscow, $832 \mathrm{p}$.

\section{Відомості про авторів:}

\author{
Корощенко Микола Миколайович \\ начальник кафедри \\ Національного університету \\ “Одеська морська академія”, \\ Одеса, Україна \\ https://orcid.org/0000-0002-3445-2297
}

Харитонов Олександр Леонідович

кандидат військових наук доцент

Національного університету

“Одеська морська академія”,

Одеса, Україна

https://orcid.org/0000-0002-7285-8001

Гордієнко Андрій Миколайович

кандидат військових наук

начальник науково-дослідного відділу

Харківського національного університету

Повітряних Сил ім. І. Кожедуба,

Харків, Україна

https://orcid.org/ 0000-0001-9606-2617
Information about the authors:

\author{
Mykola Koroshchenko \\ Head of Department \\ of the National University \\ "Odessa Maritime Academy", \\ Odessa, Ukraine \\ https://orcid.org/0000-0002-3445-2297
}

\author{
Oleksandr Kharytonov \\ Candidate of Military Sciences Senior Lecturer \\ of the National University \\ "Odessa Maritime Academy", \\ Odessa, Ukraine \\ https://orcid.org/0000-0002-7285-8001 \\ Andrii Hordiienko \\ Candidate of Military Sciences \\ Chief of Scientific Research Department \\ of Ivan Kozhedub Kharkiv National \\ Air Force University, \\ Kharkiv, Ukraine \\ https://orcid.org/ 0000-0001-9606-2617
}

\section{ПРОТИВОВОЗДУШНАЯ ОБОРОНА КОРАБЛЕЙ (КАТЕРОВ) ВОЕННО-МОРСКИХ СИЛ УКРАИНЫ В "ВОЙНЕ ДРОНОВ": ПРОБЛЕМЫ И ПУТИ ПОВЫШЕНИЯ ЭФФЕКТИВНОСТИ}

Н.Н. Корощенко, А.Л. Харитонов, А.Н. Гордиенко

В статье рассмотрен вопрос о противовоздушной обороне кораблей (катеров) Военно-Морских Сил Украины от малоразмерных беспилотных средств воздушного нападения (дронов). Проведённый анализ боевого применения и порядок действий в современных военных конфликтах малоразмерных беспилотных летательных аппаратов (БПЛА). Проведенный обобщенный анализ возможностей средств противодействия БПЛА ведущих стран мира и Украины. Представлены предложения по улучшению противовоздушной обороны (возможности противодействия) кораблей (катеров) ВМС Украины от малоразмерных БПЛА - дронов.

Ключевые слова: противовоздушная оборона, дроны, корабли, катера, способы боевого применения, боевые возможности, тактика боевого применения, принципы (основы) построения зенитного ракетного комплекса.

\section{AIR DEFENSE OF SHIPS (BOATS) OF THE NAVAL FORCES OF UKRAINE IN THE "DRONE WAR”: PROBLEMS AND WAYS TO IMPROVE EFFICIENCY}

M. Koroshchenko, O. Kharytonov, A. Hordiienko

In robotics, the problem of prototype defense of ships (boats) of the Ukrainian Navy is unimportant without impotent attacks of repeated attack (drones). In the current viynah and viyiskih konfilktakh widespread stagnation know rozv_duvalni that shock droni. For example, in the case of Syrian bulwas, Masov buli stalled Turkish shock drone with great triviality Bayraktar TB2 (Praporonosets). An analysis of the fighting capabilities of the most common prototypical defense defenses showing that you can't help them to be able to take control of the ships and boats of the attack and strike forces. Comrades in the Syrian Arab Republic showed a little lower efficiency of protection of the Russian defense. Navigate those complex systems, which are designed to deal with small, impaired, small devices, such as the Pantsir-S1, did not show the declared effectiveness, and because of them the bullets themselves were familiar with Turkish drones. Thus, today's optimal complex of fighting with drones can include a mobile repeat complex, to the extent of a certain rational turn on the number of manifestations, induction, refreshment, and it's possible to run on their own platform. Thus, the entire complex of fighting with drones can be called the repeated complex of fighting with low-sized UAVS - drones (PKBD). The article deals with the issue of air defense of ships (boats) of the Naval Forces of Ukraine against small-sized unmanned aerial attack vehicles (drones). The analysis of the combat use and the order of actions in modern military conflicts of small unmanned aerial vehicles (UAVS). A generalized analysis of the capabilities of UAV countermeasures from the leading countries of the world and Ukraine. Proposals are presented to improve the air defense (countermeasures) of ships (boats) of the Ukrainian Navy against small-sized UAVs - drones.

Keywords: air defense, drones, ships, boats, methods of combat use, combat capabilities, tactics of combat use, principles (foundations) of building an air defence missile system. 